Article

\title{
Hydroxycobalamin Reveals the Involvement of Hydrogen Sulfide in the Hypoxic Responses of Rat Carotid Body Chemoreceptor Cells
}

\author{
Teresa Gallego-Martin ${ }^{1,2,3, *}$, Jesus Prieto-Lloret ${ }^{1,2} \mathbb{D}$, Philip I. Aaronson ${ }^{4} \mathbb{(}$, Asuncion Rocher ${ }^{1,2}$ \\ and Ana Obeso ${ }^{1,2}$ (1) \\ 1 Departamento de Bioquímica y Biología Molecular y Fisiología. Facultad de Medicina. Universidad de \\ Valladolid. Instituto de Biología y Genética Molecular-CSIC, 47005 Valladolid, Spain; \\ jesus.prieto@uva.es (J.P.-L.); rocher@ibgm.uva.es (A.R.); aobeso@ibgm.uva.es (A.O.) \\ 2 Centro de Investigación Biomédica en Red de Enfermedades Respiratorias (CIBERES-ISCIII), \\ 28029 Madrid, Spain \\ 3 Division of Pulmonary, Allergy and Critical Care Medicine, School of Medicine, University of Pittsburgh, \\ Pittsburgh, PA 15213, USA \\ 4 Department of Inflammation Biology, School of Immunology and Microbial Sciences, Faculty of Life \\ Sciences and Medicine, King's College, London SE1 1UL, UK; philip.aaronson@kcl.ac.uk \\ * Correspondence: tgallego@ibgm.uva.es
}

Received: 12 December 2018; Accepted: 9 March 2019; Published: 13 March 2019

\begin{abstract}
Carotid body (CB) chemoreceptor cells sense arterial blood $\mathrm{PO}_{2}$, generating a neurosecretory response proportional to the intensity of hypoxia. Hydrogen sulfide $\left(\mathrm{H}_{2} \mathrm{~S}\right)$ is a physiological gaseous messenger that is proposed to act as an oxygen sensor in CBs, although this concept remains controversial. In the present study we have used the $\mathrm{H}_{2} \mathrm{~S}$ scavenger and vitamin $\mathrm{B}_{12}$ analog hydroxycobalamin $(\mathrm{Cbl})$ as a new tool to investigate the involvement of endogenous $\mathrm{H}_{2} \mathrm{~S}$ in $\mathrm{CB}$ oxygen sensing. We observed that the slow-release sulfide donor GYY4137 elicited catecholamine release from isolated whole carotid bodies, and that $\mathrm{Cbl}$ prevented this response. $\mathrm{Cbl}$ also abolished the rise in $\left[\mathrm{Ca}^{2+}\right]_{\mathrm{i}}$ evoked by $50 \mu \mathrm{M}$ NaHS in enzymatically dispersed CB glomus cells. Moreover, $\mathrm{Cbl}$ markedly inhibited the catecholamine release and $\left[\mathrm{Ca}^{2+}\right]_{\mathrm{i}}$ rise caused by hypoxia in isolated CBs and dispersed glomus cells, respectively, whereas it did not alter these responses when they were evoked by high $\left[\mathrm{K}^{+}\right]_{\mathrm{e}}$. The L-type $\mathrm{Ca}^{2+}$ channel blocker nifedipine slightly inhibited the rise in $\mathrm{CB}$ chemoreceptor cells $\left[\mathrm{Ca}^{2+}\right]_{i}$ elicited by sulfide, whilst causing a somewhat larger attenuation of the hypoxia-induced $\mathrm{Ca}^{2+}$ signal. We conclude that $\mathrm{Cbl}$ is a useful and specific tool for studying the function of $\mathrm{H}_{2} \mathrm{~S}$ in cells. Based on its effects on the $\mathrm{CB}$ chemoreceptor cells we propose that endogenous $\mathrm{H}_{2} \mathrm{~S}$ is an amplifier of the hypoxic transduction cascade which acts mainly by stimulating non-L-type $\mathrm{Ca}^{2+}$ channels.
\end{abstract}

Keywords: carotid body; hydrogen sulfide; hypoxia; hydroxycobalamin; oxygen sensing

\section{Introduction}

The carotid bodies (CB), located in the vicinity of the carotid artery bifurcations, are formed by clusters of two types of parenchymatous cells, chemoreceptor and sustentacular. Cell clusters are surrounded by a dense net of capillaries and penetrated by sensory nerve endings of the carotid sinus nerve (CSN) which form synaptic contacts with chemoreceptor cells; the soma of CSN fibres are located in the petrosal ganglion and project centrally to the nucleus tractus solitarius. Chemoreceptor cells sense the $\mathrm{PO}_{2}, \mathrm{PCO}_{2}$, and $\mathrm{pH}$ from nearby capillaries, becoming activated when $\mathrm{PO}_{2}$ decreases and / or $\mathrm{PCO}_{2} /\left[\mathrm{H}^{+}\right]$increases. Activation of chemoreceptor cells by either hypoxia or acidosis results 
in an increase of the ongoing basal normoxic/normohydric release of neurotransmitters leading to an increase in the action potential frequency in the CSN. Activity of the CSN is integrated in the brainstem to generate cardiorespiratory responses which act to restore blood gases to normal levels [1,2].

The chemoreceptor cell mechanisms linking the presentation of the stimulus to the activation of the exocytotic release of neurotransmitters, i.e., the sensory transduction cascades, are not fully understood. A commonly accepted transduction cascade for hypoxia consists of the following steps: detection of hypoxia by an oxygen sensor $\rightarrow$ coupling of the sensor to oxygen-sensitive $\mathrm{K}^{+}$channels $\rightarrow$ change in $\mathrm{K}^{+}$channel kinetics resulting in a decrease in their opening probability $\rightarrow$ chemoreceptor cell depolarization $\rightarrow$ activation of voltage-operated $\mathrm{Ca}^{2+}$ channels $\rightarrow$ increase in intracellular Ca ${ }^{2+}$ levels $\rightarrow$ exocytosis of neurotransmitters [2]. Several laboratories have recently proposed that hydrogen sulfide $\left(\mathrm{H}_{2} \mathrm{~S}\right.$; hereafter referred to as sulfide as it exists as a mixture of $\mathrm{H}_{2} \mathrm{~S}$ and $\mathrm{HS}^{-}$at physiological $\mathrm{pH}$ ) is an oxygen sensor, or an important positive regulator of the oxygen transduction cascade, in chemoreceptor cells [3-10]. Although Prabhakar's laboratory argues that $\mathrm{H}_{2} \mathrm{~S}$ is generated via activation of cystathionine- $\gamma$-lyase (CSE), according to a study by Li et al. [5] sulfide is produced by cystathionine $\beta$-synthetase (CBS). In contrast, Fitzgerald et al. [11] proposed that the increased rate of endogenous sulfide production that occurs during hypoxia would act as a brake to prevent chemoreceptor cells from becoming over-excited by intense hypoxic stimulus, and other laboratories have questioned the existence of any physiological role for endogenous sulfide in chemoreception, contending for example that the concentrations of sulfide donors (and therefore of sulfide) required to evoke either cellular effects at the CB level or reflex ventilatory effects are so high that their effects would represent an effect of cytochrome oxidase poisoning much like that of cyanide [12-16]. Thus, the physiological significance of endogenously produced sulfide in the transduction cascade of hypoxic stimulus in chemoreceptor cells is far from clear.

In order to further characterize the potential physiological significance of endogenously generated sulfide, in the present study we describe for the first time the use of the hydroxyl form of vitamin $B_{12}$ or hydroxycobalamin as a new tool for studying the role of sulfide as a mediator of cell responses (hydroxycobalamin is protonated to $\mathrm{H}_{2} \mathrm{O}$-cobalamin in physiological buffer, and we therefore refer to it as $\mathrm{Cbl}$ ). The upper coordination bond of the cobalt in $\mathrm{Cbl}$ is made with a hydroxyl group which is displaced by $\mathrm{H}_{2} \mathrm{~S}$ to form sulfhydrylcobalamin; the reaction is analogous to that occurring with $\mathrm{HCN}$ in forming cyanocobalamin. $\mathrm{Cbl}$ is therefore an effective and rapid sulfide scavenger; Van de Louw and Haouzi [17] showed that within 10 min of mixing $100 \mu \mathrm{M}$ with an equimolar concentration of $\mathrm{NaHS}$, the sulfide concentration in the solution fell by $\sim 95 \%$. These reactions constitute the foundation for the treatment of HCN poisoning; mice administered with i.p. Cbl were more than four times more likely to survive injection with an $\mathrm{LD}_{85}$ dose injection of $\mathrm{NaHS}$ [18], and $\mathrm{Cbl}$ is also used in humans for this purpose [19]. In vivo, vitamin $B_{12}$ in the plasma is transported into cells when bound to the protein transcobalamin (TC II); the complex binds to a receptor (TCbIR/CD320) which is endocytosed [20] and then degraded in lysosomes, releasing the $\mathrm{Cbl}$ into the cytoplasm where it is converted into methylcobalamin. $\mathrm{Cbl}$ is also transported into the mitochondria, where it is converted to $5^{\prime}$-deoxyadenosyl-cobalamin [21]. Less is known about the uptake of Cbl in the absence of TC II, although Berliner and Rosenberg demonstrated that platelets were able to take up appreciable amounts of vitamin $B_{12}$ in the absence of transcobalamin via a separate process [22]. Hall et al. (1979) also showed that HeLa cells were able to take up free vitamin $B_{12}$ in the absence of transcobalamin and that this led to the synthesis of both methyl- and 5'-deoxyadenosyl-cobalamin, suggesting that the vitamin $\mathrm{B}_{12}$ had entered both the cytoplasm and the mitochondria [23]. More recently, studies carried out in thymocytes [24] and synaptosomes [25] provide evidence that cyanocobalamin, which has a similar structure to hydroxycobalamin, is able to cross the plasmalemma in the absence of TC II when applied in vitro at supraphysiological concentrations. 
Therefore, it would be predicted that $\mathrm{Cbl}$, if applied before $\mathrm{H}_{2} \mathrm{~S}$ donors, should suppress their effects. More importantly, Cbl should scavenge sulfide produced by CSE, CBS, and other enzymes, which are present in the cytoplasm and/or the mitochondria [26]. Employing a sulfide scavenger has several potential advantages over using current methods designed to reduce cellular [sulfide] in order to evaluate its effects, particularly with regard to hypoxia. For example, it is possible that blocking or knocking out the enzymes that synthesize sulfide does not prevent an increase in its cellular concentration during hypoxia. Since there are multiple sources of sulfide within cells, both enzymatic and non-enzymatic [26], and since hypoxia is proposed to increase the cellular [sulfide] by blocking its metabolism [10], its concentration might still rise under reduced oxygen conditions if only one of these sources is removed. Additionally, the use of mice in which CSE, thought to be primarily responsible for sulfide production in the cardiovascular system, has been knocked out has been criticized because these animals demonstrate a striking rise in plasma homocysteine [27]. In contrast, Cbl would be predicted to prevent a rise in sulfide, regardless of its cause, without causing toxicity.

Accordingly, we examined whether two $\mathrm{H}_{2} \mathrm{~S}$ donors, the classical sodium hydrogen sulfide (NaHS) and the more physiological releaser GYY4137, activated catecholamine release by freshly isolated rat $\mathrm{CBs}$ in a fully Cbl-sensitive manner, as well as whether $\mathrm{Cbl}$ blocked catecholamine release caused by different levels of hypoxia and high $\mathrm{K}^{+}$-evoked depolarization. The results demonstrated that $\mathrm{Cbl}$ ablated responses to both GYY4137 and NaHS and inhibited hypoxia-induced catecholamine release elicited at several levels of hypoxia $\sim 80 \%$ in freshly isolated intact CBs but was ineffective in modifying the release response elicited by 25,35 , and $60 \mathrm{mM}$ extracellular $\mathrm{K}^{+}$. In isolated chemoreceptor cells, $\mathrm{Cbl}$ also abolished the rise in $\left[\mathrm{Ca}^{2+}\right]_{i}$ elicited by $\mathrm{NaHS}$, inhibited the hypoxia-induced $\mathrm{Ca}^{2+}$ response $\sim 70 \%$, and left intact the response elicited by high $\mathrm{K}^{+}$. We conclude that endogenous $\mathrm{H}_{2} \mathrm{~S}$ has a specific physiological action in enhancing hypoxic responses in chemoreceptor cells; this may involve mainly the stimulation of T-type voltage-gated $\mathrm{Ca}^{2+}$ channels. Some preliminary data from this study were presented at the XIXth meeting of the International Society for Arterial Chemoreception held in Leeds in July 2014 [28].

\section{Materials and Methods}

\subsection{Animals and Anesthesia Surgical Procedures}

Experiments were performed using CBs from adult male Wistar rats (280-350 g body weight). Animals were anaesthetized with sodium pentobarbital $(60 \mathrm{mg} / \mathrm{kg}$, i.p.) dissolved in physiological saline, and then euthanized by an intracardiac overdose of sodium-pentobarbital. In handling the animals, we followed the European Union Directive for Protection of Vertebrates Used for Experimental and Other Scientific Ends (2010/63/EU). Protocols were reviewed and approved by the University of Valladolid Institutional Committee for Animal Care and Use (Project Approval Ethical Code: 4505502)

After tracheostomy, bilateral blocks of tissue containing the carotid bifurcations were removed and placed in a dissecting chamber filled with ice-cold $\mathrm{O}_{2}$-saturated Tyrode solution (in $\mathrm{mM}: \mathrm{NaCl}, 140$; $\mathrm{KCl}, 5 ; \mathrm{CaCl}_{2}, 2 ; \mathrm{MgCl}_{2}, 1.1$; HEPES, 10; glucose, 5.5; $\left.\mathrm{pH}=7.4\right)$. The CBs were cleaned of surrounding tissue under a dissecting microscope and saved in glass vials containing $\mathrm{O}_{2}$-saturated ice-cold Tyrode for use within the next hour.

\subsection{Isolation and Chemoreceptor Cell Culture}

CBs were incubated $\left(12 \mathrm{~min} ; 37^{\circ} \mathrm{C}\right)$ in nominally $\mathrm{Ca}^{2+}$ - and $\mathrm{Mg}^{2+}$-free Tyrode's solution $(\mathrm{pH}=7.2)$ containing collagenase $(2.5 \mathrm{mg} / \mathrm{mL}$, type $\mathrm{IV}$, Sigma) and bovine serum albumin (BSA; $6 \mathrm{mg} / \mathrm{mL}$, Fraction V, Sigma). After removing the solution, the CBs were incubated for $17 \mathrm{~min}$ period in a new Tyrode solution containing trypsin $(1 \mathrm{mg} / \mathrm{mL}$, type II, Sigma) and BSA $(6 \mathrm{mg} / \mathrm{mL})$. The trypsin-containing solution was removed, and the tissues were mechanically disrupted by aspiration through a P1000 pipette in $2 \mathrm{~mL}$ of culture medium (DMEM) supplemented with $10 \%$ fetal bovine serum, $2 \mathrm{mM} \mathrm{L-glutamine,} \mathrm{and} \mathrm{1 \%} \mathrm{penicillin/streptomycin/fungizone.} \mathrm{After} \mathrm{centrifugation}$ 
(2000 rpm, $7 \mathrm{~min}$ ), the supernatant was discarded, and the cell pellet was resuspended in $100 \mu \mathrm{L}$ of fresh culture medium. Dispersed cells were plated as 10-20 $\mu \mathrm{L}$ drops on small poly-L-lysine-coated coverslips kept in 12 well plates and maintained in a humidified incubator $\left(37{ }^{\circ} \mathrm{C} ; 5 \% \mathrm{CO}_{2}\right.$ in air). Once the cells attached (45 min after plating), $1.5 \mathrm{~mL}$ of DMEM was added into each well to maintain the cells until use (16-24 h later).

\subsection{H-Catecholamine $\left({ }^{3} \mathrm{H}-\mathrm{CA}\right)$ Release Experiments Using Intact CBs}

General procedures used to label chemoreceptor cell CA deposits and to later study their release have been described in previous publications [29]. Analytical methods have previously been described in detail [30]. In brief, CBs were incubated $\left(2 \mathrm{~h} ; 37^{\circ} \mathrm{C}\right)$ in Tyrode solution containing the CA precursor, ${ }^{3} \mathrm{H}$-tyrosine, of high specific activity (40-50 Ci/mmol; Perkin-Elmer), 6-methyl-tetrahydropterine $(100 \mu \mathrm{M})$, and ascorbic acid $(1 \mathrm{mM})$. Following ${ }^{3} \mathrm{H}-\mathrm{CA}$ labeling, individual CBs were transferred to glass vials provided with caps, and with an inlet for the gas line and an outlet to avoid a pressure build-up, which contained $2 \mathrm{~mL}$ of precursor-free Tyrode bicarbonate solution (composition as above except for the substitution of $24 \mathrm{mM} \mathrm{NaCl}$ by $24 \mathrm{mM} \mathrm{NaHCO}$ ). Initial incubation in precursor-free normoxic $\left(5 \% \mathrm{CO}_{2} / 20 \% \mathrm{O}_{2} / 75 \% \mathrm{~N}_{2}\right)$ solution lasted $1 \mathrm{~h}$, with solutions renewed every $20 \mathrm{~min}$ and discarded; these incubations were made to wash out the precursor and to eliminate the readily releasable ${ }^{3} \mathrm{H}-\mathrm{CA}$ pool [30]. Thereafter, the incubating solutions $(2 \mathrm{~mL})$ were renewed every $10 \mathrm{~min}$ and collected for the analysis of their ${ }^{3} \mathrm{H}-\mathrm{CA}$ content. Specific protocols are given in the Results section. Solutions of NaHS and Cbl hydrochloride (both from Sigma-Aldrich) and (p-methoxyphenyl)-morpholino-phosphinodithioic acid (GYY4137; Cayman Chem. Co.) were freshly prepared as stock solutions and maintained in capped vials at $0-4{ }^{\circ} \mathrm{C}$ until use. ${ }^{3} \mathrm{H}$-CA concentrations of collected incubation solutions as well as CB homogenates were analyzed as described previously [30].

\subsection{Intracellular $\mathrm{Ca}^{2+}$ Measurements}

Detailed descriptions of the recording procedures and equipment can be found in previous publications [31,32]. Briefly, cells on coverslips were treated with $10 \mu \mathrm{M}$ fura-2-acetoxymethyl ester (Molecular Probes) at room temperature $\left(20-24^{\circ} \mathrm{C}\right.$ ) for $30 \mathrm{~min}$ and washed for $30 \mathrm{~min}$, and coverslips were then mounted in a perfusion chamber placed on the stage of a Nikon Diaphot 300 inverted microscope. Cells were superfused through gas impermeable lines with pre-warmed $\left(37^{\circ} \mathrm{C}\right)$ Tyrode bicarbonate equilibrated with $5 \% \mathrm{CO}_{2} / 20 \% \mathrm{O}_{2} / 75 \% \mathrm{~N}_{2}$ (except when hypoxia was used as a stimulus), which was reheated to $37^{\circ} \mathrm{C}$ at the entrance of the recording chamber. High $\mathrm{K}^{+}$solutions were prepared by replacing equimolar amounts of $\mathrm{NaCl}$ by $\mathrm{KCl}$. To apply $\mathrm{NaHS}$, perfusing solutions were equilibrated with $20 \% \mathrm{O}_{2} / 5 \% \mathrm{CO}_{2} /$ balance $\mathrm{N}_{2}$ ) at $37{ }^{\circ} \mathrm{C}$ and the reservoirs were capped. Immediately before the perfusion, the sulfide donor was added from a freshly prepared stock that was maintained at $0-4{ }^{\circ} \mathrm{C}$.

\subsection{Statistics}

All data are expressed as the mean \pm S.E.M. Statistical analysis were performed using the two-tailed Student $t$-test for unpaired data and RM one-way ANOVA, with the Greenhouse-Geisser correction and Sidak's multiple comparisons test for the $\mathrm{Ca}^{2+}$ imaging experiments. Values of $p<0.05$ were considered to indicate statistical significance.

\section{Results}

\subsection{Effects of $\mathrm{Cbl}$ on the Release of ${ }^{3} \mathrm{H}-\mathrm{CA}$ Induced by Hydrogen Sulfide Donors}

As depicted in Figure 1A, application of $200 \mu \mathrm{M}$ NaHS for $10 \mathrm{~min}$ (between 30 and 40 min on this protocol; dashed line) caused a large and reversible increase in ${ }^{3} \mathrm{H}-\mathrm{CA}$ release. After allowing the effect of sulfide to subside, $300 \mu \mathrm{M} \mathrm{Cbl}$ was then applied between 70 and $90 \mathrm{~min}$ (for $20 \mathrm{~min}$ ). In the presence of Cbl, adding $200 \mu \mathrm{M}$ NaHS to the solution (between 80 and $90 \mathrm{~min}$ ) caused no increase in ${ }^{3} \mathrm{H}-\mathrm{CA}$ 
release. In the absence of sulfide, application of $\mathrm{Cbl}$ on its own caused a small fall in catecholamine release (solid line). Figure 1B summarizes the findings of these experiments; note that the substantial response elicited by NaHS was completely eliminated when $\mathrm{Cbl}$ was present, and that application of $\mathrm{Cbl}$ on its own caused a small fall in ${ }^{3} \mathrm{H}-\mathrm{CA}$ release.

A

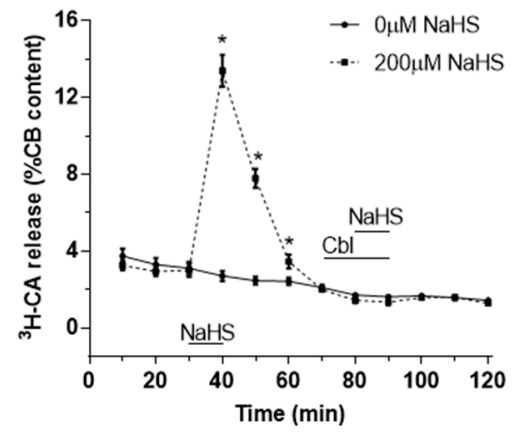

C

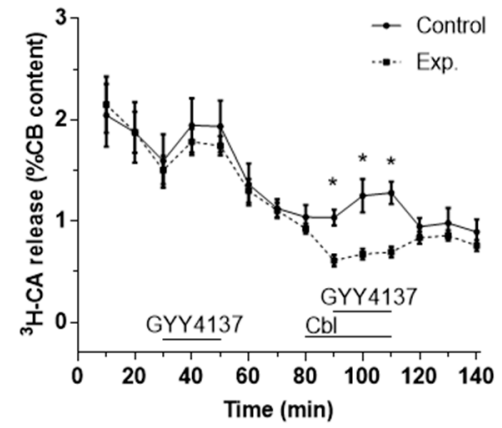

B
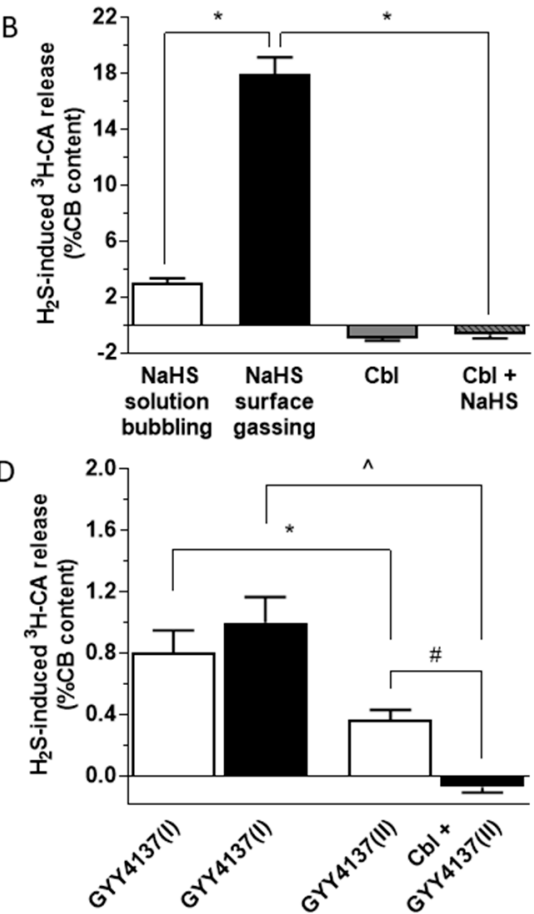

Figure 1. Effect of NaHS and GYY4137 on the release of ${ }^{3} \mathrm{H}-\mathrm{CA}$ by CB chemoreceptor cells in the presence and absence of Cbl. (A) Time course of catecholamine release elicited by $200 \mu \mathrm{M}$ NaHS applied for $10 \mathrm{~min}$. A second application of $\mathrm{NaHS}$ was in the presence of $300 \mu \mathrm{M} \mathrm{Cbl}(\mathrm{n}=6$ and 8 , for 0 and $200 \mu \mathrm{M}$ NaHS, respectively). (B) The black bar shows the magnitude of the release response corresponding to the area under the curve in part A. The empty bar represents the release response obtained for $200 \mu \mathrm{M}$ NaHS in similar experiments in which the solution rather than the headspace was gassed. The small columns in grey at the right of the figure show that $300 \mu \mathrm{M} \mathrm{Cbl}$ abolished the effect of NaHS, and that when applied alone $\mathrm{Cbl}$ caused a modest inhibition of the basal ongoing release of catecholamine (NaHS solution bubbling, $\mathrm{n}=2$; NaHS gassing surface, $\mathrm{n}=8$; $\mathrm{Cbl}, \mathrm{n}=18$; $\mathrm{Cbl}+\mathrm{NaHS}$, $n=10$ ). (C) Effect of GYY4137 on the release of ${ }^{3} \mathrm{H}-\mathrm{CA}$ in the absence and presence of Cbl. $400 \mu \mathrm{M}$ GYY4137 was applied for $20 \mathrm{~min}$ by itself at 30 and $90 \mathrm{~min}$ (continuous line); $400 \mu \mathrm{M}$ GYY4137 was applied for $20 \mathrm{~min}$ by itself at $30 \mathrm{~min}$ and then again at $90 \mathrm{~min}$, this time in the presence of $300 \mu \mathrm{M}$ $\mathrm{Cbl}$, which had been applied at $80 \mathrm{~min}$ (dashed line). $\mathrm{n}=10$ in each condition. (D) The bars show the amplitudes of the two successive responses to GYY4137 (area under the curve) when both responses were evoked in the absence of $\mathrm{Cbl}$ (empty bars) and when the second response was elicited in the presence of Cbl. Symbols indicate where there was a significant effect.

In the experiments shown in Figure $1 \mathrm{~A}$ the incubating solutions were pre-equilibrated at $37^{\circ} \mathrm{C}$ with a water vapor-saturated gas mixture $\left(20 \% \mathrm{O}_{2} / 5 \% \mathrm{CO}_{2} / 75 \% \mathrm{~N}_{2}\right)$, and throughout the experiments the headspace in the vials above the solutions was continually gassed. We also examined the effect of $200 \mu \mathrm{M}$ NaHS on ${ }^{3} \mathrm{H}$-CA release using an identical protocol to that shown in Figure 1A, except that the solution itself rather than the headspace above it was bubbled with the same gas mixture. As shown in Figure 1B (white bar) the effect of applying $200 \mu \mathrm{M}$ NaHS was greatly diminished if the solution itself was bubbled. This observation would imply that bubbling the solutions directly causes the outgassing of $\mathrm{H}_{2} \mathrm{~S}$ released into the solution by $\mathrm{NaHS}$, and in fact a similar phenomenon occurs when $\mathrm{NaCN}$ is used as a stimulating agent [33]. Therefore, in the subsequent ${ }^{3} \mathrm{H}-\mathrm{CA}$ release experiments described 
below, the equilibrating gas mixture was always applied to the vials above the surface of the incubating solution in an effort to reduce the loss of sulfide from the solution.

An important criticism of experiments using NaHS as a sulfide donor is that the concentrations required to obtain cellular responses are typically high and, in addition, that the time course of $\mathrm{H}_{2} \mathrm{~S}$ release from NaHS is nearly instantaneous. Conversely, the production of endogenous $\mathrm{H}_{2} \mathrm{~S}$ by enzyme-catalyzed reactions in cells is likely to occur in lesser amounts, at a much slower rate, and more steadily. Therefore, using NaHS may not provide a good model for the biological effects of naturally produced $\mathrm{H}_{2} \mathrm{~S}$ [34]. To address this issue, several new generations of sulfide donors have been synthesized [35]. Among them ( $p$-methoxyphenyl)-morpholino-phosphinodithioic acid (GYY4137) has been proven to release sulfide at a much lower rate and with a long-lasting time course generating cell responses considered to be more physiologically relevant [36]. When tested in the CBs (Figure 1C), GYY4137 $(400 \mu \mathrm{M})$ indeed caused a small but significant ${ }^{3} \mathrm{H}-\mathrm{CA}$ release. A response to GYY4137 was also observed during a second application (Figure 1C, solid line), although this was smaller than the first response (Figure 1C, black line; Figure 1D, II vs. I). This second response was abolished by $\mathrm{Cbl}$ (Figure 1C, dashed line). In addition, an inhibitory effect of $\mathrm{Cbl}$ on basal ${ }^{3} \mathrm{H}-\mathrm{CA}$ release is apparent at the 90 min point just prior to the application of GYY4137, implying that that endogenous sulfide production contributes to the genesis of basal normoxic release of ${ }^{3} \mathrm{H}-\mathrm{CA}$. These results are quantitated in Figure 1D.

\subsection{Effects of $\mathrm{Cbl}$ on the Release of ${ }^{3} \mathrm{H}-\mathrm{CA}$ Induced by Hypoxic and High External $\mathrm{K}^{+}$Stimulation of the Carotid Body}

Figure 2A-C show the effects of $\mathrm{Cbl}$ on the release of ${ }^{3} \mathrm{H}-\mathrm{CA}$ induced by hypoxic stimuli of three different intensities. Stimuli consisted of the incubation of the $\mathrm{CBs}$ for $10 \mathrm{~min}$ in solutions equilibrated with gas mixtures containing $2 \% \mathrm{O}_{2}\left(\mathrm{PO}_{2} \approx 13 \mathrm{mmHg}\right), 5 \% \mathrm{O}_{2}\left(\mathrm{PO}_{2} \approx 33 \mathrm{mmHg}\right)$, and $7 \% \mathrm{O}_{2}\left(\mathrm{PO}_{2} \approx\right.$ $46 \mathrm{mmHg}$ ). As shown in Figure $2 \mathrm{~A}-\mathrm{C}$, for each intensity of hypoxia, both control and experimental $\mathrm{CBs}$ were stimulated twice with the hypoxic stimulus. The controls were stimulated twice (at 30-40 and 80-90 $\mathrm{min}$ ) with hypoxia alone, whereas the experimental CBs were stimulated first with hypoxia alone at 30-40 min and then at 80-90 min following a 10 min preincubation with $300 \mu \mathrm{M} \mathrm{Cbl}$, which was also present throughout the hypoxic challenge. This experimental design allowed us to calculate the ratio of the release response in the second (SII) to the first (SI) presentation of the stimulus for both control and experimental CBs (see below).

In every case (Figure $2 \mathrm{~A}-\mathrm{C}$ ), it is evident that in drug-free hypoxic stimulations the release response elicited by hypoxia developed fully during the $10 \mathrm{~min}$ hypoxic period, was maintained at a similar level over the next $10 \mathrm{~min}$, and then fell progressively over the subsequent two or three normoxic incubating periods that followed. When present during only the hypoxic stimulus, $\mathrm{Cbl}$ markedly depressed the component of the ${ }^{3} \mathrm{H}-\mathrm{CA}$ release response measurable during hypoxia, but seemed to have no significant effect on release during the normoxic incubating periods that followed. This pattern of the inhibition prompted a further group of experiments using the most intense hypoxic stimulus $\left(2 \% \mathrm{O}_{2}\right)$ in which $\mathrm{Cbl}$ was applied $10 \mathrm{~min}$ prior to and throughout the $10 \mathrm{~min}$ of hypoxia, and then also during the two $10 \mathrm{~min}$ normoxic periods that followed. The results of these experiments are shown in Figure 2D.

In order to quantitate the effects of Cbl shown in Figure 2, we calculated the SII/SI ratios in the absence and presence of the vitamin $\mathrm{B}$ analog, during the period of hypoxia and during the subsequent normoxic period during which ${ }^{3} \mathrm{H}$-CA release was falling back to the basal level. These results are presented in Figure 3. As shown in Figure 3A-C, when $\mathrm{Cbl}$ was present before and during hypoxia, but not afterwards, it very strongly suppressed the release of ${ }^{3} \mathrm{H}-\mathrm{CA}$ evoked by each level of hypoxia but had no significant effect on catecholamine release during the subsequent period of normoxia. On the other hand, as shown in Figure 3D, if $\mathrm{Cbl}$ was left in the solution for the 20 min following hypoxia, it suppressed ${ }^{3} \mathrm{H}-\mathrm{CA}$ release both during hypoxia, and afterwards. These results are consistent 
with the possibility that elevations in chemoreceptor cell sulfide levels may persist transiently following hypoxia, slowing the recovery of baseline catecholamine release.
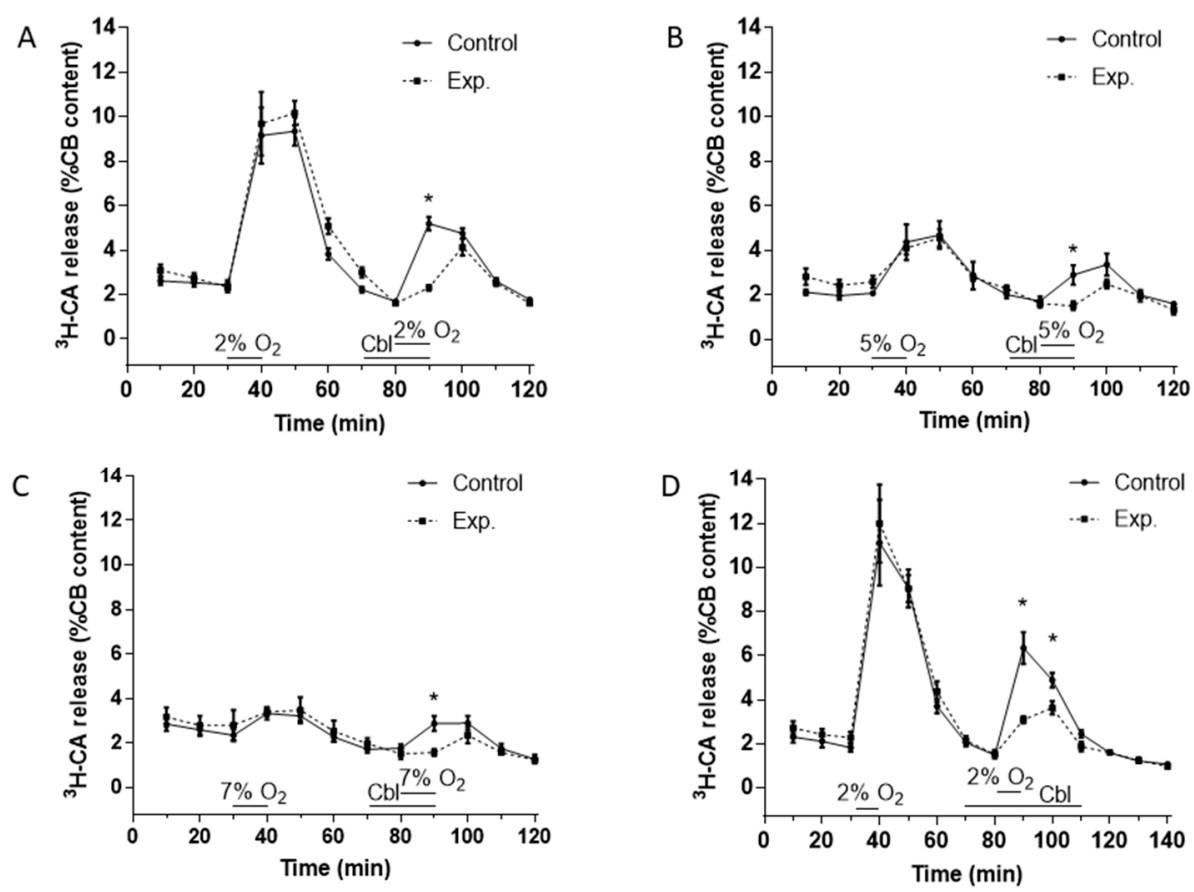

Figure 2. Effects of $\mathrm{Cbl}$ on ${ }^{3} \mathrm{H}-\mathrm{CA}$ release response elicited by different levels of hypoxia. The continuous lines in (A), (B), and (C) show the effects on catecholamine release of successive exposures of CBs (at 40-50 min, SI, and 80-90 min, SII) to $2 \% \mathrm{O}_{2}\left(\mathbf{A}, \mathrm{n}=12\right.$ in each group), 5\% $\mathrm{O}_{2}$ (B, $\mathrm{n}=5$ in each group), and $7 \% \mathrm{O}_{2}(\mathbf{C}, \mathrm{n}=5$ in each group) under control conditions, whereas the dashed lines illustrate catecholamine release evoked by a similar protocol when $300 \mu \mathrm{M} \mathrm{Cbl}$ was present between 70 and 90 min. (D). Protocol similar to panels A except that $\mathrm{Cbl}$ was present both during and after the second hypoxic challenge (from 70 to $110 \mathrm{~min}$ ), $\mathrm{n}=8$ and 12, control and experimental group, respectively. Asterisks connote time points where there were significant differences between the amplitudes of ${ }^{3} \mathrm{H}-\mathrm{CA}$ release observed in $\mathrm{CBs}$ which were exposed or not exposed to $\mathrm{Cbl}$.

We used a similar protocol to investigate the effects of $\mathrm{Cbl}$ on ${ }^{3} \mathrm{H}-\mathrm{CA}$ release evoked by high external $\mathrm{K}^{+}$(60 mM, see Figure 4A; 35 and $25 \mathrm{mM}$, not shown) and found that the effect of these purely depolarizing stimuli was not obviously affected by $300 \mu \mathrm{M} \mathrm{Cbl}$. Analysis of the effects of $\mathrm{Cbl}$ on catecholamine release both during the presence of $\mathrm{K}^{+}$and subsequent recovery period in control Tyrode solution was carried out separately as described above for hypoxia. As illustrated in Figure 4B, this confirmed that there was no significant effect of $\mathrm{Cbl}$ during either period. Likewise, a further analysis in which ${ }^{3} \mathrm{H}$-CA release was summed over both periods revealed no significant effect of $\mathrm{Cbl}$ (not shown).

\subsection{Effects of $\mathrm{Cbl}$ on the Intracellular Calcium Transients Induced by NaHS, Hypoxia, and High External $\mathrm{K}^{+}$}

Figure 5A shows mean +/ - SEM 340/380 fluorescence ratio from 74 cells of the $\mathrm{Ca}^{2+}$ transients elicited in chemoreceptor cells by $50 \mu \mathrm{M}$ NaHS under normoxic conditions. In contrast, the same concentration of the sulfide donor in the presence of $300 \mu \mathrm{M} \mathrm{Cbl} \mathrm{had} \mathrm{no} \mathrm{effect} \mathrm{on}\left[\mathrm{Ca}^{2+}\right]_{\mathrm{i}}$. A subsequent pulse of high $\mathrm{K}^{+}(35 \mathrm{mM})$ to assess the responsiveness of the cells to depolarization induced the expected rise in $\left[\mathrm{Ca}^{2+}\right]_{i}$. 
A

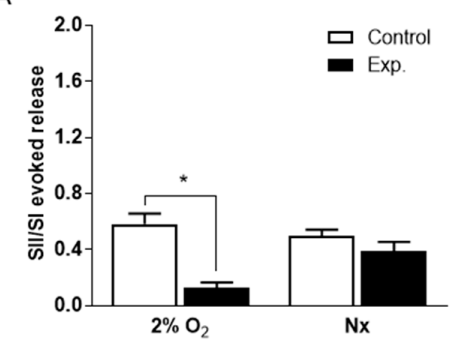

C

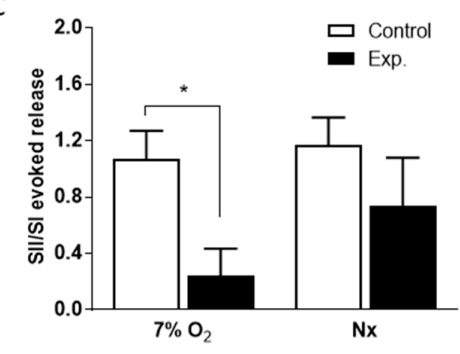

B

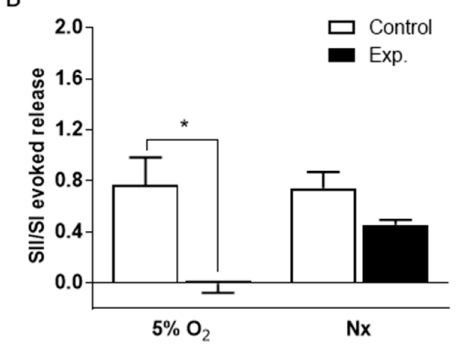

D

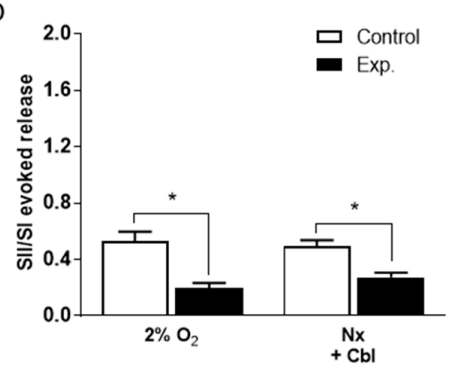

Figure 3. Mean effects of $300 \mu \mathrm{M} \mathrm{Cbl}$ on the ratio of the second and first ${ }^{3} \mathrm{H}-\mathrm{CA}$ responses to hypoxia shown in Figure 2. Results were calculated separately for ${ }^{3} \mathrm{H}-\mathrm{CA}$ release during hypoxia and during the subsequent 20 min of normoxia (Nx) during which release fell back to the baseline. (A)-(C) Mean effects of $\mathrm{Cbl}$ on the ratio of the second and first responses to hypoxia for 2, 5, and $7 \% \mathrm{O}_{2}$; $\mathrm{Cbl}$ was present for $10 \mathrm{~min}$ before and during the second hypoxic period. (D) Mean effects of $\mathrm{Cbl}$ on the ratio of the second and first responses to hypoxia for $2 \% \mathrm{O}_{2} ; \mathrm{Cbl}$ was present for $10 \mathrm{~min}$ before and during the second hypoxic period, as well as during the subsequent $20 \mathrm{~min}$ of normoxia. Asterisks indicate where there was a significant effect of Cbl. Number of replicates for each condition as is indicated in Figure 2.
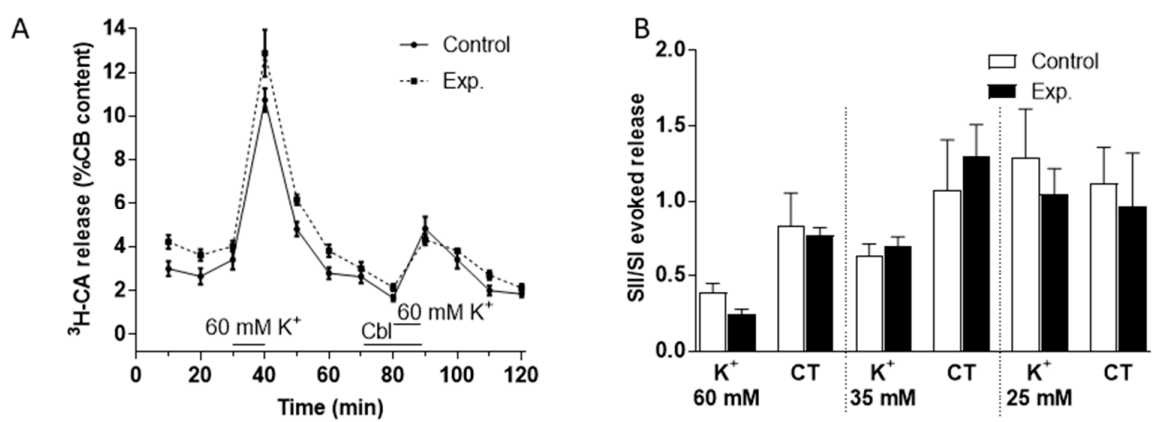

Figure 4. Effects of $\mathrm{Cbl}$ on the ${ }^{3} \mathrm{H}-\mathrm{CA}$ release response elicited by three elevated levels of extracellular $\mathrm{K}^{+}$. (A) The continuous line in shows the effects on catecholamine release of successive exposures of CBs (at 30-40 min, SI, and 80-90 min, SII) to $60 \mathrm{mM} \mathrm{K}^{+}$( $\mathrm{n}=5$ in each condition) under control conditions, whereas the dashed lines illustrate catecholamine release evoked by a similar protocol when $300 \mu \mathrm{M} \mathrm{OH}-\mathrm{Cbl}$ was present between 70 and $90 \mathrm{~min}$. (B) Bars illustrate the ratio of the second and first responses to high $\mathrm{K}^{+}$in the presence and absence of $\mathrm{Cbl}$ during the 10 min of high $\mathrm{K}^{+}$and during the subsequent 20 min period in control Tyrode $(\mathrm{CT})$ solution $\left(\mathrm{K}^{+} 5 \mathrm{mM}\right)$ during which catecholamine release remained elevated with 60,35 , and $25 \mathrm{mM}(\mathrm{n}=5$ in each condition).

The averaged $\mathrm{Ca}^{2+}$ signal obtained from 74 cells subjected to this protocol reveals that neither $\mathrm{Cbl}$ itself nor $50 \mathrm{mM}$ NaHS applied in the presence of $\mathrm{Cbl}$ had a significant effect on $\left[\mathrm{Ca}^{2+}\right]_{\mathrm{i}}$. Figure $5 \mathrm{~B}$ shows mean running integrals of the fluorescence signals ( $\Delta$ fluorescence $/ \mathrm{min}$ ) [31] obtained in these chemoreceptor cells when exposed to these conditions. It is evident that $\mathrm{Cbl}$ abolished the $\mathrm{Ca}^{2+}$ response elicited by $50 \mu \mathrm{M}$ NaHS. Figure $5 \mathrm{C}$ shows the mean results obtained in 43 chemoreceptor cells using hypoxia as a stimulus. Experiments were performed following a sandwich-type protocol [32]: after several minutes of recording under normoxic conditions, a first hypoxic stimulus (perfusing 
solutions $\mathrm{pH} 7.4$ bubbled with $5 \% \mathrm{CO}_{2}-95 \% \mathrm{~N}_{2}$; peak hypoxia in the recording chamber $\approx 10 \mathrm{mmHg}$; $\left[\mathrm{N}_{2}(\mathrm{I})\right]$ in Figure $\left.5 \mathrm{C}\right)$ for $2 \mathrm{~min}$ was applied. Following a subsequent 5-8 min period of recording under normoxic conditions, we started perfusion with a normoxic solution containing $300 \mu \mathrm{M} \mathrm{Cbl}$ for $1 \mathrm{~min}$, immediately followed by a second hypoxic stimulus ([Cbl $+\mathrm{N}_{2}$ (II)]). After an additional normoxic recovery period in the absence of $\mathrm{Cbl}$, a final hypoxic stimulus $\left(\left[\mathrm{N}_{2}(\mathrm{III})\right]\right)$ was then applied. It is evident that $\mathrm{Cbl}$ reversibly inhibited the hypoxia-induced $\mathrm{Ca}^{2+}$ signal by $\sim 70 \%$. In an identical group of experiments using $35 \mathrm{mM} \mathrm{K}^{+}$as a stimulus in 45 chemoreceptor cells (Figure 5D), application of an analogous protocol demonstrated that $\mathrm{Cbl}$ did not affect the rise in $\left[\mathrm{Ca}^{2+}\right]_{\mathrm{i}}$ induced by the pure depolarizing stimulus.

A

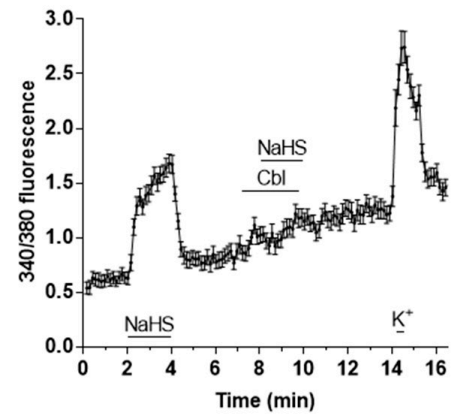

C

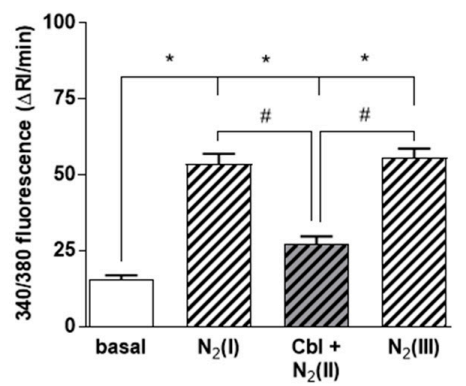

B

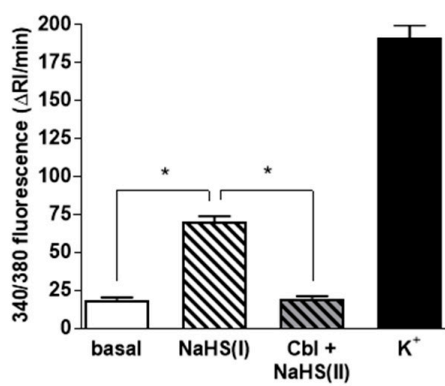

D

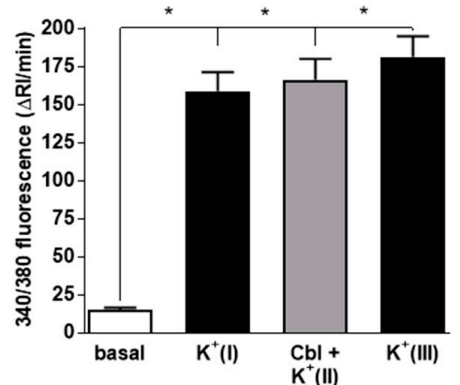

Figure 5. Effects of $\mathrm{Cbl}$ on the intracellular $\mathrm{Ca}^{2+}$ responses elicited by $50 \mu \mathrm{M}$ NaHS, hypoxia, and high external $\mathrm{K}^{+}$. $\left[\mathrm{Ca}^{2+}\right]_{i}$ was assessed as the $\mathrm{F} 340 / \mathrm{F} 380$ fluorescence emission ratio in isolated chemoreceptor cells loaded with fura-2. (A) Mean +/- SEM 340/380 fluorescence ratio (calculated every $8 \mathrm{~s}$ ) from 74 cells stimulated with NaHS in the absence and presence of $300 \mu \mathrm{M} \mathrm{Cbl}$. The response to high $\mathrm{K}^{+}$at the end demonstrates cell viability. The fast $\mathrm{Ca}^{2+}$ transient in response to high $\mathrm{K}^{+}$at the end of experiments demonstrates that cell was viable. (B) Mean running integrals of the basal and stimulated fluorescence signals ( $\Delta$ fluorescence/min) obtained from the 74 chemoreceptor cells recorded as in (A). (C) Mean running integrals of the fluorescence signals obtained in 43 cells recorded following the sequence depicted in the figure consisting of the application of three identical hypoxic stimuli (perfusion with $5 \% \mathrm{CO}_{2} / 95 \% \mathrm{~N}_{2}$ ) except that the middle hypoxic challenge was applied in the presence of $300 \mu \mathrm{M} \mathrm{Cbl}$. (D) Mean values obtained in 44 cells in a similar 'sandwich' style experiment using high $(35 \mathrm{mM})$ external $\mathrm{K}^{+}$as the stimulus. Symbols connote significant differences between the columns indicated.

In further experiments we compared the mechanisms by which hypoxia and NaHS were causing a rise in $\mathrm{CB}$ cell $\left[\mathrm{Ca}^{2+}\right]_{\mathrm{i}}$. As shown in Figure $6 \mathrm{~A}, \mathrm{~B}$ removal of $\mathrm{Ca}^{2+}$ from the solution caused a similar and profound suppression of the $\mathrm{Ca}^{2+}$ transients elicited by both $50 \mu \mathrm{M} \mathrm{NaHS}$ and hypoxia (measured in 66 and 48 chemoreceptor cells, respectively). This was consistent with the well-established role of $\mathrm{Ca}^{2+}$ influx via voltage-gated channels in the hypoxic response [37] and indicated that the rise in $\left[\mathrm{Ca}^{2+}\right]_{i}$ caused by NaHS was also due to $\mathrm{Ca}^{2+}$ influx. As shown in Figure $6 \mathrm{C}$, a component of the $\mathrm{Ca}^{2+}$ influx response to hypoxia, measured in 24 cells, was blocked by the L-type voltage-gated $\mathrm{Ca}^{2+}$ channel blocker nifedipine $(2 \mu \mathrm{M})$. Whereas two successive hypoxia-induced $\mathrm{Ca}^{2+}$ transients were similar in size under control conditions (Figure $5 C$ ), as shown in Figure $6 \mathrm{D}$, the rise in $\left[\mathrm{Ca}^{2+}\right]_{\mathrm{i}}$ elicited by $50 \mu \mathrm{M}$ NaHS tended to increase during the second exposure to this sulfide donor (51 chemoreceptor 
cells). This increase was significantly smaller when $2 \mu \mathrm{M}$ nifedipine was present during the second response (Figure 6E; measured in 50 cells), indicating that this drug was also blocking the response to sulfide (28\% inhibition). However, nifedipine diminished the response to hypoxia to a significantly greater extent than it did the response to NaHS (compare Figure 6D,E).
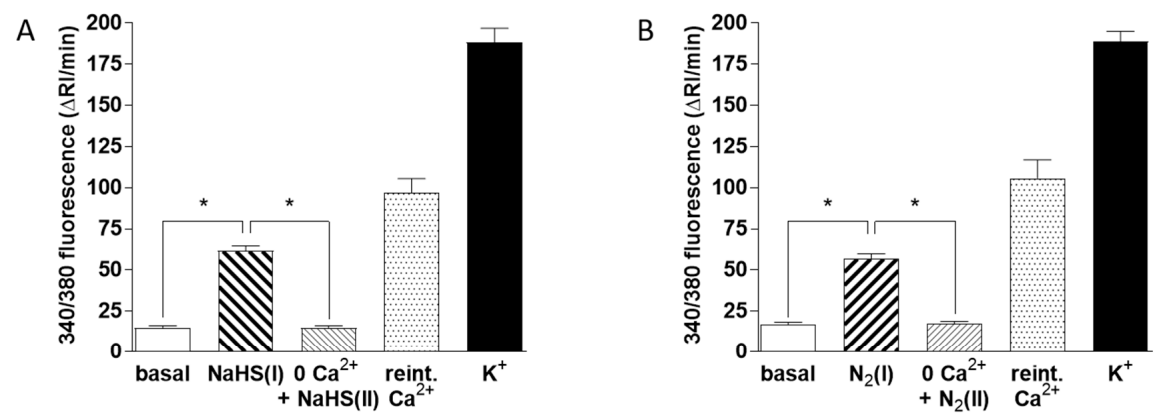

C

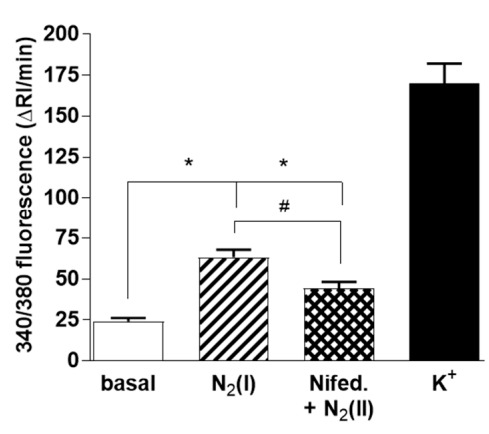

E

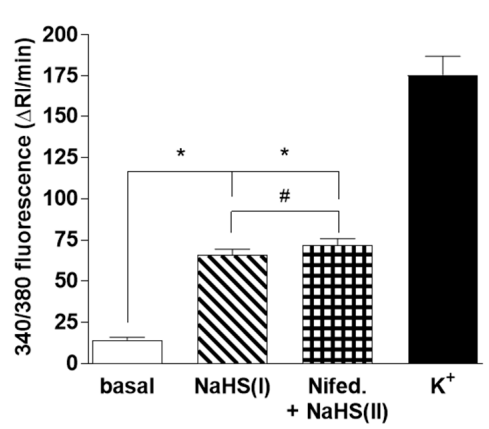

D

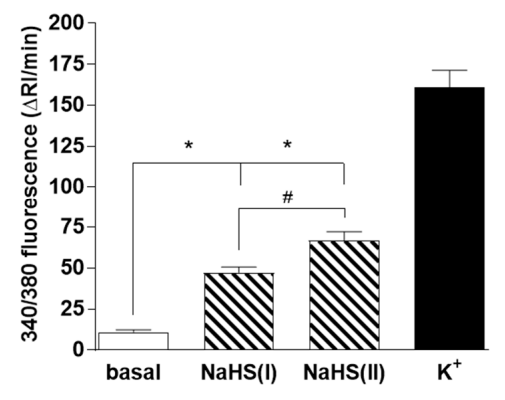

F

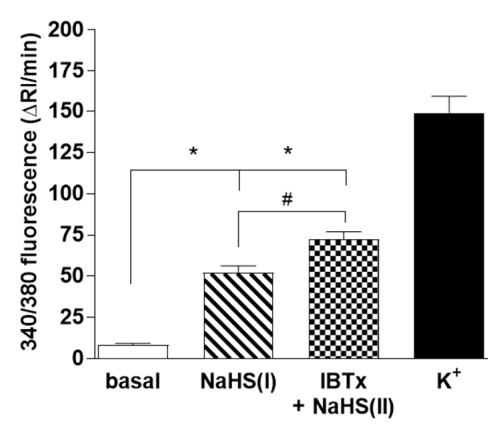

Figure 6. Mechanisms of $\mathrm{Ca}^{2+}$ influx induced by hypoxia and $50 \mu \mathrm{M} \mathrm{NaHS}$. $\left[\mathrm{Ca}^{2+}\right]_{\mathrm{i}}$ was assessed as the F340/F380 fluorescence emission ratio in isolated chemoreceptor cells loaded with fura-2. In all cases the protocols followed the same pattern: a first exposure to hypoxia or NaHS, subsequent application of the experimental condition $0 \mathrm{mM} \mathrm{Ca}^{2+}(1 \mathrm{~min}, \mathbf{A}, \mathbf{B}), 2 \mu \mathrm{M}$ nifedipine ( $3 \mathrm{~min}, \mathbf{C}$ and $\mathbf{E}$ ), or $100 \mathrm{nM}$ IBTx (1 min, F) followed by that condition with hypoxia or NaHS and finally high $\mathrm{K}^{+}$to demonstrate that cells were viable. Bars in all panels indicated the running integrals of the fluorescence signals $(\Delta$ fluorescence/min) obtained during the various conditions. (A) Effect of $\mathrm{Ca}^{2+}$ free solution on the $\mathrm{Ca}^{2+}$ signal caused by NaHS ( $n=66$ cells). (B) Effect of $\mathrm{Ca}^{2+}$ free solution on the $\mathrm{Ca}^{2+}$ signal evoked by hypoxia ( $\mathrm{n}=44$ cells). In both cases, $\mathrm{Ca}^{2+}$ reintroduction caused a rebound increase in the fluorescence emission ratio. (C) Effect of nifedipine on the $\mathrm{Ca}^{2+}$ signal elicited by hypoxia ( $\mathrm{n}=24$ cells). (D) $\mathrm{Ca}^{2+}$ signals evoked by two successive exposures of cells to NaHS under control conditions, data from 51 cells. (E) $\mathrm{Ca}^{2+}$ signals evoked by two successive exposures of cells to NaHS-the first under control conditions and the second in the presence of nifedipine ( $\mathrm{n}=50$ cells). (F) $\mathrm{Ca}^{2+}$ signals evoked by two successive exposures of cells to NaHS; the first under control conditions and the second in the presence of IBTx ( $n=47$ cells). Symbols connote significant differences between the columns indicated. 
As it has been proposed that sulfide-induced inhibition of $\mathrm{BK}_{\mathrm{Ca}}$ channel activity in $\mathrm{CBs}$ may be important in $\mathrm{O}_{2}$ sensing [38], we also examined the effect of the $\mathrm{BK}_{\mathrm{Ca}}$ channel blocker iberiotoxin (IBTx; $100 \mathrm{nM}$ ) on the increase in chemoreceptor cell $\left[\mathrm{Ca}^{2+}\right]_{\mathrm{i}}$ caused by sulfide (47 chemoreceptor cells). As shown in Figure 6F, IBTx had no effect on this response (compare Figure 6D,F).

\section{Discussion}

The main findings of this study can be summarized as follows: (1) the hydrogen sulfide donors NaHS and GYY4137 stimulated ${ }^{3} \mathrm{H}-\mathrm{CA}$ release, and this response was abolished by $300 \mu \mathrm{M}$ $\mathrm{Cbl}$; (2) $\mathrm{Cbl}$ diminished the hypoxia-induced release of ${ }^{3} \mathrm{H}-\mathrm{CA}$ by $75-100 \%$, and eliminated and reduced the intracellular $\mathrm{Ca}^{2+}$ transients elicited by $50 \mu \mathrm{M} \mathrm{NaHS}$ and hypoxia, respectively, by $\sim 70 \%$; (3) in contrast, neither the release of ${ }^{3} \mathrm{H}-\mathrm{CA}$ nor the $\mathrm{Ca}^{2+}$ transients elicited by high external $\mathrm{K}^{+}$were affected by $\mathrm{Cbl}$; (4) nifedipine caused a relatively small inhibition in the rise in $\mathrm{CB}$ chemoreceptor cells $\left[\mathrm{Ca}^{2+}\right]$ elicited by sulfide whilst attenuating the $\mathrm{Ca}^{2+}$ signal caused by hypoxia to a greater extent; (5) IBTx had no effect on the $\mathrm{Ca}^{2+}$ transients elicited by NaHS in chemoreceptor cells. The physiological forms of vitamin $\mathrm{B}_{12}$ in mammalian cells are methylcobalamin and $5^{\prime}$-deoxyadenosyl-cobalamin, with hydroxycobalamin being one of the most abundant forms of vitamin $B_{12}$ in the diet. Cyanocobalamin and hydroxycobalamin are the forms of vitamin $B_{12}$ used most commonly for therapy. The cellular uptake of vitamin $B_{12}$ from the blood depends on its binding to the plasma protein transcobalamin II (TC II); this complex binds to a membrane receptor (TCbIR/CD320), which is then endocytosed [20]. Released when the endocytosed receptor is processed in lyososomes, vitamin $B_{12}$ is methylated in the cytoplasm and, also in its hydroxycobalamin form, is transferred to mitochondria to form $5^{\prime}$-deoxyadenosyl-cobalamin [21]. This uptake process is $\mathrm{Ca}^{2+}$ and energy-dependent, and is saturable with an affinity constant in the subnanomolar range [20], which is appropriate in that the total plasma concentration of vitamin $B_{12}$ is $\sim 0.3 \mathrm{nM}$, with about $25 \%$ of this bound to TC II [39]. However, there is evidence that vitamin $B_{12}$ uptake into cells can occur via other pathways in vitro, and even in vivo, especially at high concentrations. For example, complete congenital TC II deficiency can be treated with very high doses of cobalamin [40]. Of more direct relevance to our work, a study of the uptake of cyanocobalamin in cultured platelets, carried out in serum-free physiological saline, demonstrated the existence of a non-saturating and $\mathrm{Ca}^{2+}$-independent component of vitamin $B_{12}$ uptake, which occurred even in TC II-deficient platelets [22]. The ability of $\mathrm{Cbl}$ to enter cells in vitro was also suggested in a study [18] in which freshly isolated hepatocytes were incubated for $30 \mathrm{~min}$ in physiological saline solution containing NaHS in sealed vials, and $100 \mu \mathrm{M} \mathrm{Cbl}$ was applied either at the same time as sulfide or 20 min subsequently. In both cases, the cytotoxic effects of sulfide were almost abolished. The observation that $\mathrm{Cbl}$ was able to exert its full protective action when added well after NaHS suggests strongly that it was able to enter cells and scavenge sulfide within them, as well as remove it from the incubation medium. Additional in vitro studies $[24,25]$ using cyanocobalamin at supraphysiological levels $(10-1000 \mu \mathrm{M})$ comparable to the concentration we used in our experiments $(300 \mu \mathrm{M})$ also suggest strongly that this form of vitamin $B_{12}$ is able to cross the plasmalemma and impact cell function in the absence of TC II. In both cases, cyanocobalamin raised the intracellular $\mathrm{Ca}^{2+}$ concentration; in thymocytes this was shown to be due mainly to inhibition of $\mathrm{Ca}^{2+}$ uptake by the endoplasmic reticulum [24], whilst in synaptosomes it appeared that the rise in $\left[\mathrm{Ca}^{2+}\right]_{\mathrm{i}}$ was mostly dependent on activation of N/P/Q type $\mathrm{Ca}^{2+}$ channels via a PKC-dependent mechanism [25]. In contrast, we did not observe a Cbl-induced rise in $\left[\mathrm{Ca}^{2+}\right]_{i}$ in $\mathrm{CB}$ chemoreceptor cells (Figure 5A), and $\mathrm{Cbl}$ did not cause a rise in catecholamine release, as would be predicted to occur if it was elevating $\left[\mathrm{Ca}^{2+}\right]_{\text {i }}$. We also saw no effect of $\mathrm{Cbl}$ on catecholamine release to high $\mathrm{K}^{+}$ depolarization, whereas the response to high $\mathrm{K}^{+}$in the rabbit CBs, where $\mathrm{P} / \mathrm{Q}$ type channels are important in $\mathrm{O}_{2}$ sensing, is strongly attenuated by blockers of these channels [41]. This implies either that these channels do not contribute to voltage-dependent $\mathrm{Ca}^{2+}$ influx in the rat CBs (which is consistent with the observation that hypoxia-induced catecholamine release by rat CBs is reduced by $\sim 95 \%$ with combined blockade of L- and T-type $\mathrm{Ca}^{2+}$ channels [42]) or that, if present, they are 
insensitive to $\mathrm{Cbl}$. In addition, depletion of $\mathrm{ER} \mathrm{Ca}^{2+}$ has no effect on catecholamine release in rat $\mathrm{CBs}$, whereas this is virtually abolished by removal of extracellular $\mathrm{Ca}^{2+}[43]$, as is the hypoxia-induced rise in $\left[\mathrm{Ca}^{2+}\right]_{\mathrm{i}}$ (see Figure $6 \mathrm{~B}$ ) Thus, we do not believe that non-sulfide-related effects on $\mathrm{CB} \mathrm{Ca}^{2+}$ handling were influencing the responses to $\mathrm{Cbl}$ which we observed.

The binding of exogenously applied sulfide by $\mathrm{Cbl}$ would be predicted to prevent it from having any effect on CB cells, and indeed this was confirmed by the results of Figure 1, which show that inclusion of $300 \mu \mathrm{M} \mathrm{Cbl}$ in the solution abolished the stimulation of ${ }^{3} \mathrm{H}-\mathrm{CA}$ release, which at the high concentration $(200 \mu \mathrm{M})$ of NaHS we used in this experiment was probably due to the block of cytochrome $\mathrm{C}$ oxidase [14]. Similarly, application of $\mathrm{Cbl}$ abolished the rise in intracellular $\left[\mathrm{Ca}^{2+}\right.$ ] induced in CB cells by $50 \mu \mathrm{M}$ extracellular NaHS (Figure 5B).

The results in Figure 1C,D demonstrate that the slow-release sulfide donor GYY4137 also activated chemoreceptor cells, stimulating their release of newly synthesized catecholamines. This figure also shows that the presence of $\mathrm{Cbl}$ in the incubating solution fully eliminated the capacity of GYY4137 to activate chemoreceptor cells. Additionally, it can be observed in Figure 1C that application of $\mathrm{Cbl}$ by itself resulted in a significant inhibition of the basal ongoing release of catecholamines. This observation implies that $\mathrm{Cbl}$ might, upon its entry into chemoreceptor cells, be eliminating the $\mathrm{H}_{2} \mathrm{~S}$ which is being produced under normoxic conditions, with the resulting inhibition of the baseline catecholamine-releasing activity of the cells. This interpretation, which would imply that endogenously generated sulfide is contributing to basal activity in chemoreceptor cells during normoxia, is consistent with the observation of Peng et al. [4] that knock out of the sulfide-synthesizing enzyme cystathionine- $\gamma$-lyase in mice caused a small but significant fall in ventilation even under normoxic conditions.

An important argument against a physiological role for sulfide, as assessed in many reports, is that the concentrations of its donors that are required to achieve effects are very high, so the presumable intracellular concentration of sulfide attained would exceed by far those resulting from endogenous production [13,14]. We therefore used GYY4137, which has not previously been employed in studies of the CBs, in an effort to generate a lower and sustained elevation of sulfide within the solution. Li et al. [36], in their original description of GYY4137, found that NaHS at a concentration of $100 \mu \mathrm{M}$ in a phosphate buffer at $\mathrm{pH} 7.4$ yielded amperometrically measured concentrations of $\mathrm{H}_{2} \mathrm{~S}$ of 25,000 and 100,000 pA at 3 and $5 \mathrm{~s}$, while GYY4137 at a concentration of $1 \mathrm{mM}$ yielded sulfide concentrations of about 1800 and $3000 \mathrm{pA}$ at 3 and $5 \mathrm{~min}$. Using additional information from Li et al. [36], it can be estimated that adding $400 \mu \mathrm{M}$ GYY 4137 to $2 \mathrm{~mL}$ of solution would generate a concentration of 10-12 and $\sim 25 \mu \mathrm{M}$ of hydrogen sulfide at the end of a 10 and 20 min incubation, respectively. However, this calculation assumes no loss of sulfide from the solution, and although we attempted to slow the escape of $\mathrm{H}_{2} \mathrm{~S}$ from our solutions by gassing the headspace in the vials (Figure 1B), the total sulfide concentration in the solution would probably have fallen rapidly and markedly during each $10 \mathrm{~min}$ incubation period because the solution was open to the atmosphere and gas was continually flowing through the headspace [44]. Moreover, sulfide is thought to enter cells as $\mathrm{H}_{2} \mathrm{~S}$, and based on the dependence of the equilibrium between $\mathrm{H}_{2} \mathrm{~S}$ and $\mathrm{HS}^{-}$on $\mathrm{pH}$, temperature, and salinity of the Tyrode solution (see [45]), we calculate that $\mathrm{pKa}$ for this equilibrium would have been 6.45 ; in this case, the $\left[\mathrm{H}_{2} \mathrm{~S}\right]$ would constitute only about $\sim 10 \%$ of the total sulfide. These considerations would imply that the cellular $\mathrm{H}_{2} \mathrm{~S}$ concentration in our experiments with GYY4137 was likely to have been in the submicromolar range, probably below the $\mathrm{Ki}_{\text {i }} \mathrm{H}_{2} \mathrm{~S}$ to inhibit cytochrome oxidase [46]. Physiologically, the fact that the $\mathrm{H}_{2} \mathrm{~S}$ degrading enzymes are mitochondrial while the $\mathrm{H}_{2} \mathrm{~S}$ synthesis occurs largely in the cytoplasm [26] probably affords adequate protection to cytochrome oxidase against high rates of $\mathrm{H}_{2} \mathrm{~S}$ production while allowing full range of cytoplasm and plasma membrane signaling by this gaseous messenger.

Whereas the effect of $\mathrm{Cbl}$ on basal ${ }^{3} \mathrm{H}-\mathrm{CA}$ release suggests that endogenous sulfide contributes to the setting of the functional activity of chemoreceptor cells under normoxic conditions, the data presented in Figures 2 and 3 go a step further to indicate that endogenous sulfide plays a significant 
role as an amplifier of the chemoreceptor cell response to hypoxia. Importantly, Cbl significantly reduced ${ }^{3} \mathrm{H}-\mathrm{CA}$ release induced by three levels of hypoxia $\left(2,5\right.$, and $\left.7 \% \mathrm{O}_{2}\right)$, in each case by $>75 \%$.

It is noteworthy that it took $\sim 20 \mathrm{~min}$ for the effect of hypoxia on ${ }^{3} \mathrm{H}-\mathrm{CA}$ release to completely subside following the re-imposition of normoxia. The elevated release of catecholamine during this period was blocked if $\mathrm{Cbl}$ was present but was not significantly reduced if $\mathrm{Cbl}$ had been present during hypoxia but was removed when normoxia was restored (compare Figure 3A,D). These data suggest that a rise in cellular [sulfide] induced by hypoxia is likely to persist transiently after hypoxia has been removed, during which period it continues to promote catecholamine release. Since $\mathrm{H}_{2} \mathrm{~S}$ diffuses rapidly across cell membranes due to its lipophilicity [44] such that cellular levels should drop very quickly if it is no longer being generated, we speculate that the persistence of the effect of sulfide could depend on a dynamic equilibrium between its binding to, and release from, cysteine residues on proteins [47]. By scavenging sulfide as it is released, Cbl would prevent its rebinding, thereby rapidly terminating signaling via its interactions with cysteine residues.

As shown in Figure 5, $50 \mu \mathrm{M}$ sulfide caused an increase in $\left[\mathrm{Ca}^{2+}\right]_{\mathrm{i}}$ in glomus cells which was abolished by $\mathrm{Cbl}$. In contrast, the rise in $\left[\mathrm{Ca}^{2+}\right]_{\mathrm{i}}$ evoked by high $\mathrm{K}^{+}$depolarization was insensitive to $\mathrm{Cbl}$. The effect of $\mathrm{Cbl}$ on the hypoxia-induced rise in $\left[\mathrm{Ca}^{2+}\right]_{\mathrm{i}}$ fell between these extremes; the $\mathrm{Ca}^{2+}$ signal was decreased by about $70 \%$. The $\mathrm{Ca}^{2+}$ signal induced by both $\mathrm{NaHS}$ and hypoxia was abolished by removal of extracellular $\mathrm{Ca}^{2+}$, indicating that it was due entirely to $\mathrm{Ca}^{2+}$ influx (Figure 6A,B).

The L-type voltage-gated $\mathrm{Ca}^{2+}$ channel blocker nifedipine diminished the $\mathrm{Ca}^{2+}$ response to hypoxia by $\sim 50 \%$, compared to the $67 \%$ decrease reported previously [37]. The discrepancy between these values is relatively small and might be due to the use of different degrees of hypoxia, but in any case, it appears that a blockade of L-type voltage-gated $\mathrm{Ca}^{2+}$ channels causes a more substantial inhibition of the response to hypoxia than it does to that of sulfide, which was reduced by $\sim 28 \%$. CB chemoreceptor cells express several types of $\mathrm{Ca}^{2+}$ channels, although only the L-type channels seem to be required for the secretory response evoked by hypoxia in rat CBs because dihydropyridines (L-type channel inhibitors) virtually abolished the hypoxia-induced secretory response [42]. However, the T-type $\mathrm{Ca}^{2+}$ channel blocker mibefradil also strongly inhibited the secretory response to hypoxia, suggesting that $\mathrm{Ca}^{2+}$ entry through these channels may amplify the response to hypoxia. Interestingly, mibefradil had no effect on catecholamine release evoked by $35 \mathrm{mM} \mathrm{K}^{+}$[42].

The partial sensitivity of the rise in $\left[\mathrm{Ca}^{2+}\right]_{\mathrm{i}}$ elicited by NaHS to nifedipine suggests that sulfide is stimulating the opening of both L- and T-type $\mathrm{Ca}^{2+}$ channels, with a predominant effect on the latter. T-type $\mathrm{Ca}^{2+}$ channels, which are not blocked by nifedipine, activate and inactivate at more negative potentials than do L-type channels. They therefore demonstrate a window current which develops with relatively small depolarizations, such as those associated with $\mathrm{O}_{2}$ sensing in the CBs $[48,49]$ and may even be present at the resting potential [50,51]. Although we did not measure membrane potential, the $\mathrm{K}^{+}$concentrations we used were substantial enough to ensure a robust depolarization, e.g., raising $\left[\mathrm{K}^{+}\right]_{\mathrm{e}}$ from 5 to $25 \mathrm{mM} \mathrm{K} \mathrm{K}^{+}$would shift the $\mathrm{K}^{+}$equilibrium potential by about $+39 \mathrm{mV}$ (assuming an intracellular $\left[\mathrm{K}^{+}\right]$of $130 \mathrm{mM}$ ). Thus, whereas T-channels could be active at the resting potential, such that their stimulation by basally generated sulfide causes low-level CB activation, they are likely to inactivate rapidly during high $\mathrm{K}^{+}$depolarization, thereby accounting for the lack of effect of $\mathrm{Cbl}$, and therefore sulfide, on catecholamine release by high $\mathrm{K}^{+}$.

The results of Figure 6 are in accord with the report by Makarenko et al. [8] that a significant component of the rise in $\left[\mathrm{Ca}^{2+}\right]_{i}$ and consequent $\mathrm{CB}$ stimulation by hypoxia is due to a sulfide-mediated activation of T-type $\mathrm{Ca}^{2+}$ channels.

There is evidence that hypoxia-induced inhibition of both TASK and $\mathrm{BK}_{\mathrm{Ca}}$ channels is important in $\mathrm{CB} \mathrm{O}_{2}$ sensing [31,52]. Although sulfide does not appear to play a role in suppressing TASK channel activity during hypoxia [14-16], sulfide-induced $\mathrm{BK}_{\mathrm{Ca}}$ channel inhibition has been observed in chemoreceptor cells, and the CBS antagonist AOAA inhibited the hypoxia-induced suppression of the $\mathrm{BK}_{\mathrm{Ca}}$ current in rat type 1 glomus cells. This has led to the proposal that this mechanism is important in chemoreceptor $\mathrm{O}_{2}$ sensing $[5,38,53]$. An implication of this model is that a sulfide-mediated block of 
$\mathrm{BK}_{\mathrm{Ca}}$ channels should contribute to the rise in chemoreceptor cell $\left[\mathrm{Ca}^{2+}\right]_{\mathrm{i}}$ triggered by hypoxia, but to date this seems not to have been examined. We therefore assessed whether the $\mathrm{BK}_{\mathrm{Ca}}$ channel blocker IBTx would suppress the effect of $50 \mu \mathrm{M}$ NaHS on $\left[\mathrm{Ca}^{2+}\right]_{i}$ and found, as shown in Figure $6 \mathrm{~F}$, that it did not. Taken with the observation that $\mathrm{Cbl}$ strongly suppresses the hypoxia-induced $\left[\mathrm{Ca}^{2+}\right]_{\mathrm{i}}$ rise in these cells, these results do not support the concept that the involvement of sulfide in $\mathrm{O}_{2}$ sensing requires $\mathrm{BK}_{\mathrm{Ca}}$ channel inhibition.

\section{Conclusions}

Our data demonstrate that $\mathrm{Cbl}$ is a useful tool for studying the function of endogenously produced sulfide, with which $\mathrm{Cbl}$ reacts and scavenges by forming the stable compound sulfhydrylcobalamin. It penetrates into cells and upon its reaction irreversibly eliminates the gaseous messenger, regardless of how it is being produced. Thus, while it is uncertain that inhibitors or knockout of individual sulfide-producing enzymes will completely eliminate increases in cellular [sulfide] during hypoxia, and there are also worries about the marked rise in plasma homocysteine which occurs in CSE knockout mice [27], Cbl would be expected to abolish a rise in sulfide, whatever its cause, without causing cell toxicity. Our use of this approach has allowed us to provide compelling and novel evidence supporting the hypothesis that endogenous sulfide contributes to $\mathrm{O}_{2}$ sensing in $\mathrm{CB}$ chemoreceptor cells and is capable of regulating their activity, both under basal conditions and during natural hypoxic stimulation. Our evidence supports the possibility that this contribution is due to the opening of T-type $\mathrm{Ca}^{2+}$ channels, as demonstrated previously by Makarenko and colleagues [8]. Thus, endogenously generated sulfide would act as a positive messenger, enhancing the gain of the hypoxic transduction cascade, especially at low to moderate levels of hypoxia.

Author Contributions: Conceptualization: T.G.-M. and P.I.A.; methodology: T.G.-M.; validation: J.P.-L. and P.I.A.; formal analysis: T.G-M. and J.P.-L.; investigation: T.G.-M.; resources: A.R. and A.O.; data curation: T.G.-M.; writing—original draft preparation: T.G.-M.; writing—review and editing: T.G.-M., J.P-L., P.I.A., A.R., and A.O.; visualization: T.G.-M.; supervision: A.R. and A.O.; project administration: A.R. and A.O.; funding acquisition: A.R. and A.O.

Funding: This research was funded by BFU2015-70616-R (MINECO/FEDER) (DGICYT), VA106G18 (JCyL), and CIBER CB06/06/0050 (CIBERES-ISCIII).

Acknowledgments: We would like to thank Teresa Agapito for her assistance with the spectroscopic experiments and $\mathrm{M}^{\mathrm{a}}$ de los Llanos Bravo, Elena Olea, and Ana Gordillo for their technical assistance. The authors of this paper dedicate it to the memory of Professor Constancio Gonzalez, deceased in June 2015, for all the guidance he gave us.

Conflicts of Interest: The authors declare no conflict of interest.

\section{References}

1. Fidone, S.; Gonzalez, C. Initiation and control of chemoreceptor activity in the carotid body. In Handbook of Physiology, Section 3, The Respiratory System, vol II, Control of Breathing; Fishman, A.P., Cherniack, N.S., Widdicombe, J.G., Geiger, S.R., Eds.; American Physiological Society: Bethesda, MD, USA, 1986; Volume 2, pp. 247-312.

2. Gonzalez, C.; Almaraz, L.; Obeso, A.; Rigual, R. Carotid body chemoreceptors: From natural stimuli to sensory discharges. Physiol. Rev. 1994, 74, 829-898. [CrossRef]

3. Olson, K.R.; Healy, M.J.; Qin, Z.; Skovgaard, N.; Vulesevic, B.; Duff, D.W.; Whitfield, N.L.; Yang, G.; Wang, R.; Perry, S.F. Hydrogen sulfide as an oxygen sensor in trout gill chemoreceptors. Am. J. Physiol. Regul. Integr. Comp. Physiol. 2008, 295, R669-R680. [CrossRef]

4. Peng, Y.J.; Nanduri, J.; Raghuraman, G.; Souvannakitti, D.; Gadalla, M.M.; Kumar, G.K.; Snyder, S.H.; Prabhakar, N.R. $\mathrm{H}_{2} \mathrm{~S}$ mediates $\mathrm{O}_{2}$ sensing in the carotid body. Proc. Natl. Acad. Sci. USA 2010, 107, 10719-10724. [CrossRef] [PubMed]

5. Li, Q.; Sun, B.; Wang, X.; Jin, Z.; Zhou, Y.; Dong, L.; Jiang, L.H.; Rong, W. A crucial role for hydrogen sulfide in oxygen sensing via modulating large conductance calcium-activated potassium channels. Antioxid. Redox Signal. 2010, 12, 1179-1189. [CrossRef] [PubMed] 
6. Makarenko, V.V.; Nanduri, J.; Raghuraman, G.; Fox, A.P.; Gadalla, M.M.; Kumar, G.K.; Snyder, S.H.; Prabhakar, N.R. Endogenous $\mathrm{H}_{2} \mathrm{~S}$ is required for hypoxic sensing by carotid body glomus cells. Am. J. Physiol. Cell Physiol. 2012, 303, C916-C923. [CrossRef] [PubMed]

7. Jiao, Y.; Li, Q.; Sun, B.; Zhang, G.; Rong, W. Hydrogen sulfide activates the carotid body chemoreceptors in cat, rabbit and rat ex vivo preparations. Respir. Physiol. Neurobiol. 2015, 208, 15-20. [CrossRef] [PubMed]

8. Makarenko, V.V.; Peng, Y.J.; Yuan, G.; Fox, A.P.; Kumar, G.K.; Nanduri, J.; Prabhakar, N.R. CaV3.2 T-type $\mathrm{Ca}^{2+}$ channels in $\mathrm{H}_{2} \mathrm{~S}-$ mediated hypoxic response of the carotid body. Am. J. Physiol. Cell Physiol. 2015, 308, C146-C154. [CrossRef] [PubMed]

9. Yuan, G.; Vasavda, C.; Peng, Y.J.; Makarenko, V.V.; Raghuraman, G.; Nanduri, J.; Gadalla, M.M.; Semenza, G.L.; Kumar, G.K.; Snyder, S.H.; et al. Protein kinase G-regulated production of $\mathrm{H}_{2} \mathrm{~S}$ governs oxygen sensing. Sci. Signal. 2015, 8, ra37. [CrossRef] [PubMed]

10. Olson, K.R. Hydrogen sulfide is an oxygen sensor in the carotid body. Respir. Physiol. Neurobiol. 2011, 179, 103. [CrossRef]

11. Fitzgerald, R.S.; Shirahata, M.; Chang, I.; Kostuk, E.; Kiihl, S. The impact of hydrogen sulfide $\left(\mathrm{H}_{2} \mathrm{~S}\right)$ on neurotransmitter release from the cat carotid body. Respir. Physiol. Neurobiol. 2011, 176, 80-89. [CrossRef]

12. Haouzi, P.; Bell, H.; Philmon, M. Hydrogen sulfide oxidation and the arterial chemoreflex: Effect of methemoglobin. Respir. Physiol. Neurobiol. 2011, 177, 273-283. [CrossRef] [PubMed]

13. Van de Louw, A.; Haouzi, P. Inhibitory effects of hyperoxia and methemoglobinemia on $\mathrm{H}_{2} \mathrm{~S}$ induced ventilatory stimulation in the rat. Respir. Physiol. Neurobiol. 2012, 181, 326-334. [CrossRef] [PubMed]

14. Buckler, K.J. Effects of exogenous hydrogen sulphide on calcium signalling, background (TASK) K channel activity and mitochondrial function in chemoreceptor cells. Pflugers Arch. 2012, 463, 743-754. [CrossRef]

15. Kim, D.; Kim, I.; Wang, J.; White, C.; Carroll, J.L. Hydrogen sulfide and hypoxia-induced changes in TASK (K2P3/9) activity and intracellular $\mathrm{Ca}^{2+}$ concentration in rat carotid body glomus cells. Respir. Physiol. Neurobiol. 2015, 215, 30-38. [CrossRef] [PubMed]

16. Wang, J.; Hogan, J.O.; Wang, R.; White, C.; Kim, D. Role of cystathionine- $\gamma$-lyase in hypoxia-induced changes in TASK activity, intracellular $\left[\mathrm{Ca}^{2+}\right]$ and ventilation in mice. Respir. Physiol. Neurobiol. 2017, 246, 98-106. [CrossRef]

17. Van de Louw, A.; Haouzi, P. Ferric Iron and Cobalt (III) compounds to safely decrease hydrogen sulfide in the body? Antioxid. Redox Signal. 2013, 19, 510-516. [CrossRef]

18. Truong, D.H.; Mihajlovic, A.; Gunness, P.; Hindmarsh, W.; O’Brien, P.J. Prevention of hydrogen sulfide $\left(\mathrm{H}_{2} \mathrm{~S}\right)$-induced mouse lethality and cytotoxicity by hydroxocobalamin (vitamin B(12a)). Toxicology 2007, 242, 16-22. [CrossRef]

19. Borron, S.W.; Baud, F.J.; Megarbane, B.; Bismuth, C. Hydroxocobalamin for severe acute cyanide poisoning by ingestion or inhalation. Am. J. Emerg. Med. 2007, 25, 551-558. [CrossRef]

20. Quadros, E.V.; Sequeira, J.M. Cellular uptake of cobalamin: Transcobalamin and the TCblR/CD320 receptor. Biochimie 2013, 95, 1008. [CrossRef]

21. Depeint, F.; Bruce, W.R.; Shangari, N.; Mehta, R.; O’Brien, P.J. Mitochondrial function and toxicity: Role of B vitamins on the one-carbon transfer pathways. Chem. Biol. Interact. 2006, 163, 113-132. [CrossRef]

22. Berliner, N.; Rosenberg, L.E. Uptake and metabolism of free cyanocobalamin by cultured human fibroblasts from controls and a patient with transcobalamin II deficiency. Metabolism 1981, 30, 230. [CrossRef]

23. Hall, C.A.; Hitzig, W.H.; Green, P.D.; Begley, J.A. Transport of therapeutic cyanocobalamin in the congenital deficiency of transcobalamin II (TC II). Blood 1979, 53, 251. [PubMed]

24. Sukocheva, O.A.; Abramov, A.Y.; Levitskaya, J.O.; Gagelgans, A.I.; Carpenter, D.O. Modulation of intracellular $\mathrm{Ca}\left({ }^{2+}\right)$ concentration by vitamin $\mathrm{B} 12$ in rat thymocytes. Blood Cells Mol. Dis. 2001, $27,812$. [CrossRef] [PubMed]

25. Hung, K.L.; Wang, C.C.; Huang, C.Y.; Wang, S.J. Cyanocobalamin, vitamin B12, depresses glutamate release through inhibition of voltage-dependent $\mathrm{Ca}^{2+}$ influx in rat cerebrocortical nerve terminals (synaptosomes). Eur. J. Pharmacol. 2009, 602, 230. [CrossRef] [PubMed]

26. Olson, K.R. Hydrogen sulfide, reactive sulfur species and coping with reactive oxygen species. Free Radic. Biol. Med. 2019. [CrossRef]

27. Edwards, G.; Feletou, M.; Weston, A.H. Hydrogen sulfide as an endothelium-derived hyperpolarizing factor in rodent mesenteric arteries. Circ. Res. 2012, 110, e13-e14. [CrossRef] 
28. Gallego-Martin, T.; Agapito, T.; Ramirez, M.; Olea, E.; Yubero, S.; Rocher, A.; Gomez-Nino, A.; Gonzalez, C.; Obeao, A. Experimental observations on the biological significance of sulphide in the carotid body chemoreception. In Proceedings of the XIXth International Society for Arterial Chemoreception (ISAC), Leeds, UK, 29 June-3 July 2014. Unpublished conference paper.

29. Vicario, I.; Rigual, R.; Obeso, A.; Gonzalez, C. Characterization of the synthesis and release of catecholamine in the rat carotid body in vitro. Am. J. Physiol. Cell Physiol. 2000, 278, C490-C499. [CrossRef]

30. Conde, S.V.; Obeso, A.; Vicario, I.; Rigual, R.; Rocher, A.; Gonzalez, C. Caffeine inhibition of rat carotid body chemoreceptors is mediated by A2A and A2B adenosine receptors. J. Neurochem. 2006, 98, 616-628. [CrossRef]

31. Gomez-Nino, A.; Obeso, A.; Baranda, J.A.; Santo-Domingo, J.; Lopez-Lopez, J.R.; Gonzalez, C. MaxiK potassium channels in the function of chemoreceptor cells of the rat carotid body. Am. J. Physiol. Cell Physiol. 2009, 297, C715-C722. [CrossRef]

32. Gallego-Martin, T.; Fernandez-Martinez, S.; Rigual, R.; Obeso, A.; Gonzalez, C. Effects of low glucose on carotid body chemoreceptor cell activity studied in cultures of intact organs and in dissociated cells. Am. J. Physiol. Cell Physiol. 2012, 302, C1128-C1140. [CrossRef]

33. Obeso, A.; Almaraz, L.; Gonzalez, C. Effects of cyanide and uncouplers on chemoreceptor activity and ATP content of the cat carotid body. Brain Res. 1989, 481, 250-257. [CrossRef]

34. Li, L.; Rose, P.; Moore, P.K. Hydrogen sulfide and cell signaling. Annu. Rev. Pharmacol. Toxicol. 2011, 51, 169-187. [CrossRef] [PubMed]

35. Powell, C.R.; Dillon, K.M.; Matson, J.B. A review of hydrogen sulfide $\left(\mathrm{H}_{2} \mathrm{~S}\right)$ donors: Chemistry and potential therapeutic applications. Biochem. Pharmacol. 2018, 149, 110-123. [CrossRef] [PubMed]

36. Li, L.; Whiteman, M.; Guan, Y.Y.; Neo, K.L.; Cheng, Y.; Lee, S.W.; Zhao, Y.; Baskar, R.; Tan, C.H.; Moore, P.K. Characterization of a novel, water-soluble hydrogen sulfide-releasing molecule (GYY4137): New insights into the biology of hydrogen sulfide. Circulation 2008, 117, 2351-2360. [CrossRef]

37. Buckler, K.J.; Vaughan-Jones, R.D. Effects of hypoxia on membrane potential and intracellular calcium in rat neonatal carotid body type I cells. J. Physiol. 1994, 476, 423-428. [CrossRef] [PubMed]

38. Kemp, P.J.; Telezhkin, V. Oxygen sensing by the carotid body: Is it all just rotten eggs? Antioxid. Redox Signal. 2014, 20, 794-804. [CrossRef]

39. Garrod, M.G.; Green, R.; Allen, L.H.; Mungas, D.M.; Jagust, W.J.; Haan, M.N.; Miller, J.W. Fraction of total plasma vitamin B12 bound to transcobalamin correlates with cognitive function in elderly Latinos with depressive symptoms. Clin. Chem. 2008, 54, 1210. [CrossRef] [PubMed]

40. Hitzig, W.H.; Dohmann, U.; Pluss, H.J.; Vischer, D. Hereditary transcobalamin II deficiency: Clinical findings in a new family. J. Pediatr. 1974, 85, 622. [CrossRef]

41. Rocher, A.; Geijo-Barrientos, E.; Caceres, A.I.; Rigual, R.; Gonzalez, C.; Almaraz, L. Role of voltage-dependent calcium channels in stimulus-secretion coupling in rabbit carotid body chemoreceptor cells. J. Physiol. 2005, 562 Pt 2, 407. [CrossRef]

42. Caceres, A.I.; Gonzalez-Obeso, E.; Gonzalez, C.; Rocher, A. RT-PCR and pharmacological analysis of L-and T-type calcium channels in rat carotid body. Adv. Exp. Med. Biol. 2009, 648, 105-112. [CrossRef]

43. Conde, S.V.; Caceres, A.I.; Vicario, I.; Rocher, A.; Obeso, A.; Gonzalez, C. An overview on the homeostasis of $\mathrm{Ca}^{2+}$ in chemoreceptor cells of the rabbit and rat carotid bodies. Adv. Exp. Med. Biol. 2006, 580, 215. [PubMed]

44. Olson, K.R.; DeLeon, E.R.; Liu, F. Controversies and conundrums in hydrogen sulfide biology. Nitric Oxide 2014, 41, 11-26. [CrossRef] [PubMed]

45. Sitdikova, G.F.; Fuchs, R.; Kainz, V.; Weiger, T.M.; Hermann, A. Phosphorylation of BK channels modulates the sensitivity to hydrogen sulfide $\left(\mathrm{H}_{2} \mathrm{~S}\right)$. Front. Physiol. 2014, 5, 431. [CrossRef] [PubMed]

46. Cooper, C.E.; Brown, G.C. The inhibition of mitochondrial cytochrome oxidase by the gases carbon monoxide, nitric oxide, hydrogen cyanide and hydrogen sulfide: Chemical mechanism and physiological significance. J. Bioenerg. Biomembr. 2008, 40, 533-539. [CrossRef] [PubMed]

47. Koike, S.; Ogasawara, Y. Sulfur Atom in its Bound State Is a Unique Element Involved in Physiological Functions in Mammals. Molecules 2016, 21, 1753. [CrossRef] [PubMed]

48. Buckler, K.J. A novel oxygen-sensitive potassium current in rat carotid body type I cells. J. Physiol. 1997, 498 Pt 3, 649-662. [CrossRef] 
49. Donnelly, D.F. Are oxygen dependent K+ channels essential for carotid body chemo-transduction? Respir. Physiol. 1997, 110, 211. [CrossRef]

50. Bijlenga, P.; Liu, J.H.; Espinos, E.; Haenggeli, C.A.; Fischer-Lougheed, J.; Bader, C.R.; Bernheim, L. T-type alpha $1 \mathrm{H} \mathrm{Ca}^{2+}$ channels are involved in $\mathrm{Ca}^{2+}$ signaling during terminal differentiation (fusion) of human myoblasts. Proc. Natl. Acad. Sci. USA 2000, 97, 7627-7632. [CrossRef] [PubMed]

51. Chevalier, M.; Lory, P.; Mironneau, C.; Macrez, N.; Quignard, J.F. T-type CaV3.3 calcium channels produce spontaneous low-threshold action potentials and intracellular calcium oscillations. Eur. J. Neurosci. 2006, 23, 2321-2329. [CrossRef] [PubMed]

52. Buckler, K.J.; Williams, B.A.; Honore, E. An oxygen-, acid- and anaesthetic-sensitive TASK-like background potassium channel in rat arterial chemoreceptor cells. J. Physiol. 2000, 525 Pt 1, 135-142. [CrossRef]

53. Telezhkin, V.; Brazier, S.P.; Cayzac, S.; Muller, C.T.; Riccardi, D.; Kemp, P.J. Hydrogen sulfide inhibits human BK(Ca) channels. Adv. Exp. Med. Biol. 2009, 648, 65-72. [CrossRef]

(c) 2019 by the authors. Licensee MDPI, Basel, Switzerland. This article is an open access article distributed under the terms and conditions of the Creative Commons Attribution (CC BY) license (http:/ / creativecommons.org/licenses/by/4.0/). 